\title{
CMACによる非線形離散時間系のモデル追従制御*
}

\author{
山下 裕 $^{* *}$. 佐藤友彦 ${ }^{* *}$. 島公脩 ${ }^{* *}$
}

\section{Implementation of Model Following Control for Nonlinear Discrete-Time Systems by CMAC*}

\author{
Yuh Yamashita ${ }^{* *}$, Tomohiko SATOH $^{* *}$ and Masasuke Shima ${ }^{* *}$
}

\begin{abstract}
This paper discusses a design method of "neural controller" which achieves the model following control for a SISO nonlinear discrete-time system. If the system dynamics is completely known, the model following control law can be derived as a nonlinear function of input-output sequence via the nonlinear control theory. Under reasonable assumptions, a neural network CMAC-Cerebellar Model Arithmetic Computer-is able to learn both the uncertain nonlinear dynamics of the system and the nonlinear function which yields the model following controller. Moreover, in order to improve the accuracy and the speed of learning, the data presented to the CMAC are transformed by the difference method or the correlation method. It is shown by computer simulations that our method works well and the correlation method is better than the difference method.
\end{abstract}

\section{1. 緒 言}

最近，ニューラルネットワークを制御に応用する試み が数多くなされている 小 $^{1 \sim 8}$ 特に, ニューロンの非線形性 を利用して，非線形系を制御対象としたものが多いよう に見受けられる. 制御方式も, 学習制御, 適応制御など 多岐にわたっている. しかし，そてで述べられている制 御方式が，一般的にどのような制御対象に対して適用が 可能であるのかを考察したあのは少ない. また，ロボッ トなどに適用した場合には, 制御対象の状態量がすべて 観測できるものとしている場合が多い.

本論文では, ある程度一般的な非線形 1 入力 1 出力離 散時間系に対し、ニューラルネットワークの一種として 考えられている $\mathrm{CMAC}^{1}$ を用いて, 出力フィードバッ クによるモデル追従制御則を構成する. CMAC は, バッ クプロパゲーション法 ${ }^{9}$ を用いる多層型ニューラルネッ トワークなどと比べると原始的な神経回路モデルであり, ニューロンの数む多く必要となる.しかし, CMACは, 従来の計算機上でエミュレートするのに適しており，ま

* 原稿受付 1990.7.27

**. 北海道大学 工学部 Faculty of Engineering Hokkaido University ; N 13 W 8, Kita-ku, Sapporo 060, JAPAN

Key Words : nonlinear discrete-time system, model following control, CMAC (Cerebellar Model Arithmetic Computer), neural network, forced dynamics.
たニューロンの数がある程度多い場合であ収束する. CMAC を用いた制御の研究は, 参考文献 1)のほかに 参考文献 2)，3）などがある.

2. ， 3. では，入出力の過去の列によるフィードバック によって, 離散時間非線形系のモデル追従制御系を構成 できるととを示す．4. で CMAC について簡単に説明 したあと，5，6. では，CMACによって，未知の制御 対象に対してモデル追従制御系を構成するための方法を 述べる. 7. ではシミュレーションによって, 本方法の 有効性を確かめる.

\section{2. 状態フィードバックによるモデル追従 制御}

非線形離散時間系の制御に関してはすでに，いくつ かの論文が発表されている ${ }^{10 \sim 17}$. 特に，1 入力 1 出力系 については, 局所的に可制御であれば局所的に入出力 線形化 ${ }^{10}$ が可能であり, 線形系の制御理論が応用可能 である.また, NARMA (Nonlinear ARMA) モデ ルで表わされた系に対しても，モデル追従形の適応 . 学習制御 ${ }^{11}$ などが研究されている. こてでは, 1 入力 1 出 力系に対する局所的なモデル追従制御について述べる.

しばらくは，制御対象のダイナミクスが既知であるも のとして考える. 制御対象は,

$$
x(t+1)=f(x(t), u(t))
$$




$$
y(t)=h(x(t))
$$

で表わされるものとする. ただし， $t \in\{0,1,2, \cdots\}$ は 離散的な時間を表わすとととする. また, $u(t), y(t)$, $x(t) \triangleq \operatorname{col} .\left(x^{1}(t), \cdots, x^{n}(t)\right) \in \boldsymbol{R}^{n}$ はそれぞれ $t$ におけ るスカラ入力, スカラ出力, 状態量を表わし, $f(x, u)$, $h(x)$ は解析的な写像とする. また，規範モデルを,

$$
\begin{aligned}
& x_{M}(t+1)=f_{M}\left(x_{M}(t), v(t)\right) \\
& y_{M}(t)=h_{M}\left(x_{M}(t)\right)
\end{aligned}
$$

とする. ただし, $x_{M}(t) \triangleq \operatorname{col} .\left(x_{M}{ }^{1}(t), \cdots, x_{M}{ }^{n_{M}}(t)\right) \in$ $\boldsymbol{R}^{n_{M}}, v(t), y_{M}(t)$ は，それぞれ規範モデルの状態量, 入力, 出力である.

本論文では，次の仮定 1 を満たす軌道を生成する入力 $u(t), v(t)$ のみを考える.

仮定 1 次の 3 条件を仮定する.

（1）ある領域 $\boldsymbol{W} \subset \boldsymbol{R}^{n+1}$ が存在して, $(x(k), u(k))$ が $W$ 上のみを動く.

(2) $\boldsymbol{W}$ の $x$ 空間への射影を $\boldsymbol{X}, \boldsymbol{X}$ の $h(x)$ による像を $\boldsymbol{Y}, y_{M}$ の動く領域を $\boldsymbol{Y}_{M}$ とすると, $\boldsymbol{Y} \supset \boldsymbol{Y}_{M}$.

（3） $x$ を固定したときの $\boldsymbol{W}$ の切片を $\boldsymbol{U}(x)$ としたとき, $\boldsymbol{U}(x)(x \in \boldsymbol{X})$ は単連結である. また, $u \rightarrow h(f(x$, $u)$ ）による $U(x)$ の像を $\boldsymbol{Y}^{\prime}(x)$ とすると, $x \in \boldsymbol{X}$ に 対して $\boldsymbol{Y}^{\prime}(x) \supset \boldsymbol{Y}$.

(1) の条件は, $f(x, u)$ の定義域を制限するあのであ り, (2) は, 制御対象の出力のとり得る範囲が規範モデ ルの出力のとり得る範囲よりも広くなくてはならないと いう条件である. また (3) は， $y_{1} \in \boldsymbol{Y}$ を 1 つ決めたとき に, $x(t) \in \boldsymbol{X}$ に対して $y(t+1)=y_{1}$ とする入力 $u(t)$ が 必ず存在するための条件である.

本論文に挍いて，「局所的に」とは，「ての仮定 1 を満 たすように系が動く限りは」の意味で用いている.

さらに，(1)，(2) 式に対し，次の条件を仮定する.

仮定 $2 W$ に扔いて, 制御対象の Relative Order は 1 である. つまり, $(x, u) \in \boldsymbol{W}$ に対して，

$$
\frac{\partial h(f(x, u))}{\partial u} \neq 0
$$

がなりたつものとする.

ての仮定 1，2のあとでは, 次のように状態フィード バックによるモデル追従制御系を局所的に構成するとと が可能である. まず,

$$
y(t+1)-y_{M}(t+1)=a\left(y(t)-y_{M}(t)\right)
$$

となるエラーシステムを考え, 制御対象とモデルの出力 の差が (6) 式に従うとする.

$$
|a|<1
$$

を満たす $a$ に対しては,

$$
y(t)-y_{M}(t) \rightarrow 0(t \rightarrow \infty)
$$

がなりたつ.よって，(6) 式がなりたつように，u(t) を決めればよい，恒等式，

$$
\begin{aligned}
& y(t+1)-y_{M}(t+1) \\
& \quad=h(f(x(t), u(t)))-h_{M}\left(f\left(x_{M}(t), v(t)\right)\right)
\end{aligned}
$$

がなりたつので,

$$
h(f(x, u))-h_{M}\left(f\left(x_{M}, v\right)\right)=a\left(h(x)-h_{M}\left(x_{M}\right)\right)
$$

を $u(t)$ について解いた式

$$
u=\alpha\left(x, h_{M}\left(f_{M}\left(x_{M}, v\right)\right)+a\left(h(x)-h_{M}\left(x_{M}\right)\right)\right)
$$

が制御則を与える. 仮定 1 の（3）より，

$$
\begin{aligned}
& \phi\left(y_{1}, y_{2}, y_{3} ; a\right) \triangleq y_{1}+a\left(y_{2}-y_{3}\right) \\
& \boldsymbol{Y}^{\prime}(x) \supset \phi\left(\boldsymbol{Y}_{M}, \boldsymbol{Y}, \boldsymbol{Y}_{M} ; a\right), \quad x \in \boldsymbol{X}
\end{aligned}
$$

となるような $a$ が存在する. (最悪の場合, $a=0$ とす ればよい）さらに，仮定 2 がなりたっているので，(7), （13）式を満たす $a$ に対し， $\boldsymbol{W}$ 上で (10) 式の $u$ について の逆写像が存在する. $u(t)$ を構成するためには, $x_{M}(t)$ のすべての情報を必要としていない.すなわち, $x(t)$ と $h_{M}\left(f_{M}\left(x_{M}, v\right)\right)+a\left(h(x)-h_{M}\left(x_{M}\right)\right)$ の $(n+1)$ 個の 値だけでよい，仮定 1，2では，簡単のために Relative Orderを 1 としているが，2 以上であってあ同様に制御 則が構成可能である.

しかし，制御対象が線形系でゼロ点が単位円外にある 場合，乙の方法による閉ループ系は不安定となる. 非線 形系の場合も同様なととが起とりうる. たとえば, 出力 がある列 $y_{D}(0), y_{D}(1), \cdots(\in \boldsymbol{Y})$ に制御されていると する. そのとき, $h(x)=y_{D}(t)$ を満たす点の集合で定 義される多様体 $\boldsymbol{P}_{\boldsymbol{t}}$ 上では,

$$
h(f(x(t), u(t)))=y_{D}(t+1)
$$

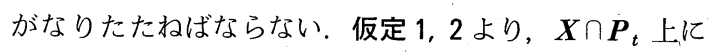
おいて, 乙のような $u(t)$ が存在するので, それを,

$$
u(t)=u_{0}\left(x(t), y_{D}(t+1)\right), \quad x(t) \in \boldsymbol{X} \cap \boldsymbol{P}_{t}
$$

と抢く. 乙こで, 局所微分同相写像 $z(x)$ による座標変 換を考える. ただし, $z(x)$ の第 1 要素は $z^{1}(x)=h(x)$ とする. $z(x)$ によって局所的に座標変換された新しい 座標を col. $\left(y, \zeta^{1}, \cdots, \zeta^{n-1}\right)$ とし, その座標であらわし た制御対象 (1) 式を,

$$
\begin{aligned}
& y(t+1)=h\left(f\left(z^{-1}(y(t), \zeta(t)), u(t)\right)\right) \\
& \zeta(t+1)=\beta(y(t), \zeta(t), u(t))
\end{aligned}
$$

とおく. $x(t) \in \boldsymbol{X} \cap \boldsymbol{P}_{t}$ とし，かっ (15) 式を満たす $u(t)$ が入力されていると仮定すると, 


$$
\begin{aligned}
& y(t)=y_{D}(t) \\
& u(t)=u_{0}\left(z^{-1}\left(y_{D}(t), \zeta(t)\right), y_{D}(t+1)\right)
\end{aligned}
$$

を（16）式，（17）式に代入することにより，（16）式は $y(t+1)=y_{D}(t+1),(17)$ 式は,

$$
\begin{aligned}
& \zeta(t+1) \\
& =\beta\left(y_{D}(t), \zeta(t), u_{0}\left(z^{-1}\left(y_{D}(t), \zeta(t)\right), y_{D}(t+1)\right)\right)
\end{aligned}
$$

となる。

任意の初期值 $x(0) \in \boldsymbol{X} \cap \boldsymbol{P}_{0}$ に対して $y(t)=y_{D}(t)$ $(k=0,1,2, \cdots)$ に拘束する状態フィードバック則のクラ スを考える.すると, そのクラスの制御則は (15) 式を 満たすので, $x(t) \in \boldsymbol{X} \cap \boldsymbol{P}_{t}(t=0,1,2, \cdots)$ ならば（つ まり, 初期值が $\boldsymbol{X} \cap \boldsymbol{P}_{0}$ 上にあるならば), そのクラスに おいて（20）式で表わされる動特性は不変である. これ を, forced dynamics と呼ぶこととする.

ここで, 次の仮定をする.

仮定 $3 y_{D}(t)=y_{M}(t)$ のとき, 規範モデルのとりうる 出力例に対して, forced dynamics (20) 式の $\zeta(t)$ は 有界である.

$y_{D}(t)=0$ の場合, forced dynamics は zero dynamics $^{12}$ と呼ばれる.

\section{3. 状態観測器の設計}

制御対象の状態量がわからない場合は, 普通は状態観 測器を用いる. 観測器を設計するときに, 通常は可観測 性の仮定が必要である.（1)，(2) 式の形の系における可 観測性の研究には, 参考文献 13), 14) などがあるが, 本論文では，局所的な可観測性として次の仮定をする.

仮定 4

$$
\begin{aligned}
& r(x, u(t), \cdots, u(t+n-2)) \\
& \triangleq \operatorname{col}(h(x), h(f(x, u(t))), \cdots \\
& \quad h(f(\cdots f(x, u(t)), \cdots, u(t+n-2))))
\end{aligned}
$$

とおいたとき，Wにおいて，

$$
\operatorname{rank} \frac{\partial \gamma(x, u(t), \cdots, u(t+n-2))}{\partial x}=n
$$

であるとと.

この仮定のあとでは，次のように局所的に（Wにおい

て）状態量を推定することができる.

$$
\begin{aligned}
& \gamma(x(t-n+1), u(t-n+1), \cdots, u(t-1)) \\
& \quad=\operatorname{col} .(y(t-n+1), \cdots, y(t))
\end{aligned}
$$

であるから, $x(t-n+1)$ について解いて,

$$
\begin{aligned}
x(t-n+1)= & \gamma^{-1}(u(t-n+1), \cdots, u(t-1), \\
& y(t-u+1), \cdots, y(t))
\end{aligned}
$$

とすることができる. よって，

$$
\begin{aligned}
& x(t)=\delta(u(t-n+1), \cdots, u(t-1) \\
& y(t-n+1),\cdots, y(t)) \\
& \triangleq f\left(\cdots f \left(f \left(\gamma^{-1}(u(t-n+1), \cdots, u(t-1),\right.\right.\right. \\
&y(t-n+1), \cdots, y(t))), \\
&u(t-n+2)), \cdots, u(t-1))
\end{aligned}
$$

と観测器を求めるととができる. この観測器は $n-1$ ス テップ後には（雑音. 誤差がないならば）真の值に収束 する.よって，乙の意味で，（25）式はデッドビートオ ブザーバである.

前節の (11) 式とあわせると, 出力フィードバックの モデル追従制御則は,

$$
\begin{aligned}
u(t)= & \alpha(\delta(u(t-n+1), \cdots, u(t-1), \\
& y(t-n+1), \cdots, y(t)), \\
& \left.\phi\left(h_{M}\left(f_{M}\left(x_{M}(t), v(t)\right)\right), y(t), y_{M}(t) ; a\right)\right)
\end{aligned}
$$

となり, 入力の過去値 $u(t-n+1), \cdots, u(t-1)$, 出力の 過去值 - 現在值 $y(t-n+1), \cdots, y(t)$, および次ステップ における出力の目標值 $\phi\left(h_{M}\left(f_{M}\left(x_{M}(t), v(t)\right)\right), y(t)\right.$, $\left.y_{M}(t) ; a\right)$ によって制御則が構成可能であるととがわ かる.

\section{4. 神経回路モデル $\mathrm{CMAC}^{1}$}

CMAC (Cerebellar Model Arithmetic Com-

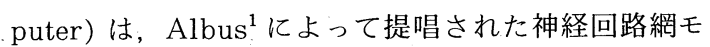
デルであり, 任意の連続関数を近似的に学習する能力を あつ. Fig.1 に扔いて, 左から入力層, 中間層, 出力層 であり, それぞれのニューロンの数は, $\left(K Q^{-} K+1\right)^{N}$, $K Q^{N}, 1$ である. ここで, $N$ は入力の数, $K$ は量子化 関数の数, $Q$ は量子化関数でとの分解能の段数之呼ばれ ている数である. 出力層を除くすべてのニューロンは 0

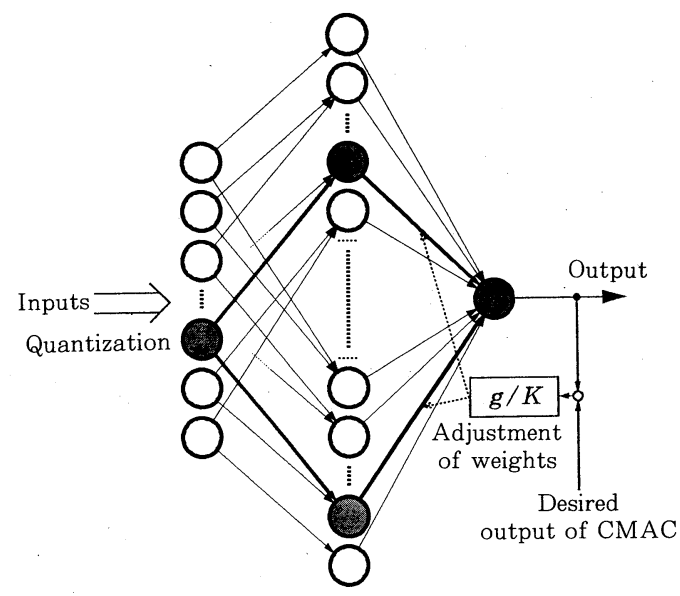

Fig. 1 Structure of CMAC 
か 1 の離散的な值を持つ.

入力層のニューロンのうち発火するのは一つだけであ る. その様子を Fig. 2 に示す. Fig. 3 は中間層のニュュー ロンが発火する様子を示したものである. $Q^{N}$ 個の二ュー ロンが格子状に配置されたものが $K$ 個ある. 入力層に 対応するニューロンが 1 格子あたり一つの発火し，中間 層全体で $K$ 個発火する. Fig. 3 で, 実線で区切られた 部分が一つのニューロンで，斜線を引いてあるニューロ ンが発火している. 中間層の出力にシナプス加重を掛け たものが出力層に入力され，それらの和が $\mathrm{CMAC}$ の出 カとなる. CMAC の学習は, 中間層と出力層の間のシ ナプス加重に対しておてなわれる，教師信号と CMAC の出力との差を $K$ で割り, 学習定数 $g(<1)$ を掛けた あのを, 出力に関与した $K$ 個のシナプス加重に加える ことにより学習が進行する.

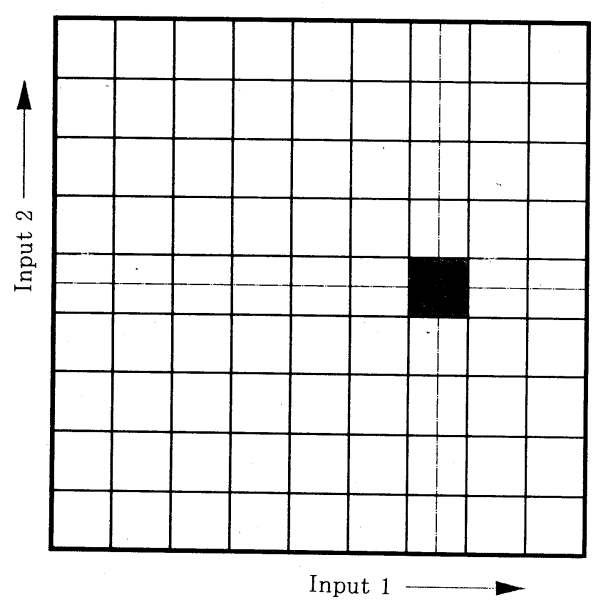

Fig. 2 Input layer of CMAC
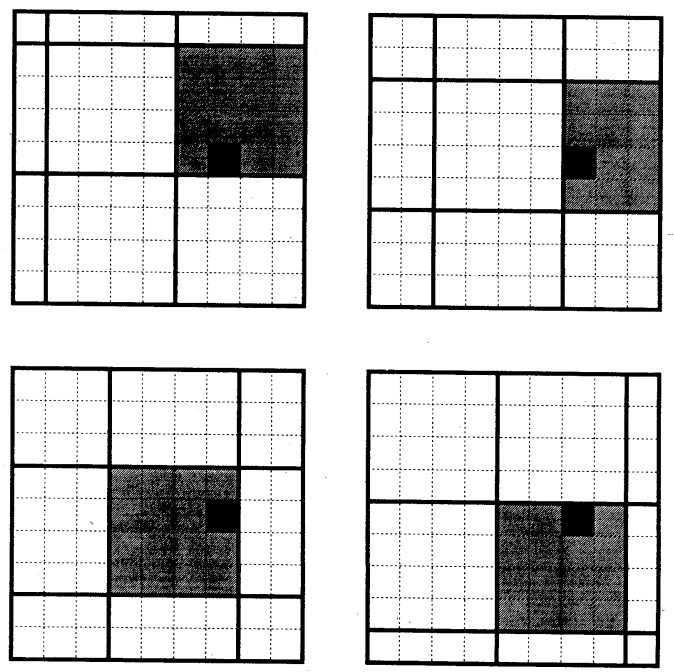

Fig, 3 Hidden layer of CMAC
CMAC を従来の計算機上で実現するときには，発火 するニューロンの数が決っているので, どのニューロン が発火したかという情報と, 中間層と出力層の間のシナ プス加重の值，および出力層の值のみを記憶しておけば よい.

$\mathrm{CMAC}$ の近似の精度はニューロンの数代依存するの で, 実際に CMACを用いる際には，適当な補間機構を 付け加え枚ばならない場合あありうる。本研究に打ける シミュレーション（7.）に扔いても，一次補間によって 最終的な出力を得ている，また，学習時にも一次補間を 用いている。

\section{CMACによるモデル追従制御}

本節では，CMAC（あるいは連続関数を学習できる ほかのニューラルネットワーク）に, 制御則 $\alpha(\delta(\cdot), \cdot)$ を学習させる方法について述べる，本節以降では，制御 対象のダイナミクスは未知とする。 ただし，系の次数だ けは既知とし，前節までの仮定がなりたっているあのと する.

本節の目的は，CMAC に (26) 式の制御則を学習さ せることである.（26）式の制御則は，次ステップに扔 ける出力を，(26）式の $\phi(\cdot)$ の部分に一致させるよう に㗢く.よって, (26) 式の $\phi(\cdot)$ の部分を $y(t+1)$ とし たうえで $t$ を $t-1$ と置きな打した式,

$$
\begin{aligned}
u(t-1)= & \alpha(\delta(u(t-n), \cdots, u(t-2) \\
& y(t-n), \cdots, y(t-1)), y(t)) .
\end{aligned}
$$

飞従って, 学習を抢てなう。すなわち, $u(t-n), \cdots$, $u(t-2), y(t-n), \cdots, y(t)$ を CMAC の入力として, $u(t-1)$ を CMAC の教師信号として与えて, 学習させ る. その様子を示したあのが, Fig.4 (a) である. 本 節では, Fig. 4 に扔いて, $u_{0}=y_{0}=0, A=I_{2 n}$ である. 学習後は, 1 ステップ時間を進めて, $u(t-n), \cdots, u(t-$ 2) の代わりに $u(t-n+1), \cdots, u(t-1)$ を, $y(t-n), \cdots$, $y(t-1)$ の代わりに $y(t-n+1), \cdots, y(t)$ を, $y(t)$ の代 わりに $\phi\left(h_{M}\left(f_{M}\left(x_{M}(t), v(t)\right)\right), y(t), y_{M}(t) ; a\right)$ を 用いる. すると, 次ステップの制御対象の出力 $y(t+1)$ が $\phi\left(h_{M}\left(f_{M}\left(x_{M}(t), v(t)\right)\right), y(t), y_{M}(t) ; a\right)$ となる ような入力 $u(t)$ が $\mathrm{CMAC}$ の出力として得られる. よっ て, それを制御対象の入力とすれば，モデル追従制御系 となる (Fig. 4 (b)).

本論文の方法の特徵をまとめると, 次の 2 点となる.

1) $\mathrm{CMAC}$ の入力として, 制御対象の入力の過去值扔 よび出力の過去值・現在值・未来の目標值を用いる.

2）多くの文献では，ニューラルネットワークの学習に 制御対象とモデルの出力の差を用いている ${ }^{2,4 \sim 6}$. し かし, 本論文では制御対象への入力を $\mathrm{CMAC}$ の教 


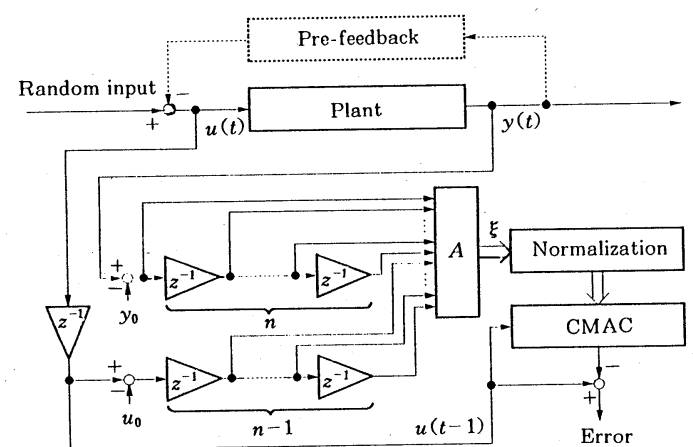

(a) Learning stage

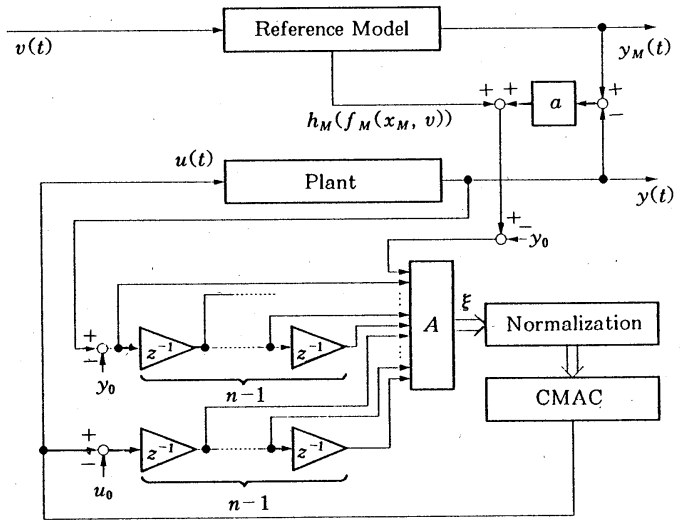

(b) Control stage

Fig. 4 Block diagram of proposed control

師信号として用い，未来の目標値の代わりに実際の出力 值を CMAC に入力する. Psalitis ${ }^{7}$ らの分類では一般 学習機構に属するが，uの過去值むニューラルネットワー クに入力するなど，異なる点あある.

\section{CMAC への入力の変換}

サンプル值系に扔いては, 通常サンプル間隔を小さく すると，極とゼロ点は単位円に近づく．そのとき，入力 にあよるが, $y(t-n), \cdots, y(t)$ の值は互いに近接した 値になることがありうる，乙のような場合， CMAC へ の入力として $u(t-n), \cdots, u(t-2), y(t-n), \cdots, y(t)$ をそのまま用いたのでは, CMAC の中間層のうち，ほ とんど用いられないニューロンが数多く存在するととと なる。

そてで本節では, $u(t-n), \cdots, u(t-2), y(t-n), \cdots$, $y(t)$ 亿簡単な一次変換を施したものを $\mathrm{CMAC}$ の入力 とし，学習の効率を向上させる二つの方法について述べ る.

一つめの方法は， $y$ および $u$ の差分をとる方法である. 学習時は, $u(t-n)-u(t-2), \cdots, u(t-3)-u(t-2)$, $u(t-2), y(t-n)-y(t-1), \cdots, y(t-2)-y(t-1)$, $y(t-1), y(t)-y(t-1)$ を CMAC の入力として用いる. 制御系を構成する時には, $u(t-n+1)-u(t-1), \cdots$, $u(t-2)-u(t-1), u(t-1), y(t-n+1)-y(t), \cdots$, $y(t-1)-y(t), y(t), \phi\left(h_{M}\left(f_{M}\left(x_{M}(t), v(t)\right)\right), y(t)\right.$, $\left.y_{M}(t) ; a\right)-y(t)$ を CMAC 亿入力する. 乙れを変換 則 1 と呼ぶこととする.

二つめの方法は, 学習時に CMAC の入力が互いに無 相関之なるような一次变換を施す方法である. CMAC の入力を $\xi \triangleq \operatorname{col} .\left(\xi^{1}, \cdots, \xi^{2 n}\right) \in \boldsymbol{R}^{2 n}$ とする. また, $\eta \triangleq$ col. $(u(t-n), \cdots, u(t-2), y(t-n), \cdots, y(t)) \in$ $R^{2 n}$ と抒き, $\eta$ から $\xi$ への変換行列を $A$ とする. つま り,

$$
\xi=A(\eta-\bar{\eta})
$$

を，適当な正規化の後，CMACに入力する. こてでは，

$$
E\left(\xi \xi^{T}\right)=I_{2 n}
$$

となるように，変換行列 $A$ を決定する. ただし， $E(\cdot)$ は期待值をあらわし， $\bar{\eta}=E(\eta)$ である.

$$
E\left(\xi \xi^{T}\right)=A E\left((\eta-\bar{\eta})(\eta-\bar{\eta})^{T}\right) A^{T}
$$

であるから

$$
A^{T} A=E\left((\eta-\bar{\eta})(\eta-\bar{\eta})^{T}\right)^{-1}
$$

を満たせばよい，Aが対象行列であると仮定すると，

$$
A=\left(E\left((\eta-\bar{\eta})(\eta-\bar{\eta})^{T}\right)^{-1}\right)^{1 / 2}
$$

と計算できる. Fig. 4 に扔いて $u_{0}=E(u), y_{0}=E(y)$ とし， $A$ を(32) 式の行列としたあのが，乙の方法に相 当している. 乙の方法を以後, 変換則 2 と呼ぶことにす る.

$E\left((\eta-\bar{\eta})(\eta-\bar{\eta})^{T}\right)$ を計算するために，あらかじめ 適当な数の入出力デー夕を必要とするが，そのデー夕は CMAC の学習にも使用できるので，より多くのデー夕 が必要となるようなととはない．また，一つめの方法で は，CMACへの入力を入力層のニューロンに振り分け る際に，適当な係数を掛けたのちにオフセット分を引い て $[0,1]$ に正規化しなければならない. 変換則 2 では, 学習に用いる $\xi$ の期待値は 0 であり, また分散む 1 で あるので, $[0,1]$ への正規化が容易である.

\section{7. シミュレーションによる検討}

本論文の方法によって CMAC にモデル追従制御則を 学習させるととができることを確認するために, 計算機 上でシミュレーションを扔てなった，また，6．亿述べ た二つの方法の比較をおてなった.

制御対象は, 


$$
\begin{aligned}
x^{1}(t+1)= & -0.4\left\{x^{1}(t)\right\}^{3}+x^{1}(t)+0.3 x^{2}(t) \\
& -0.1 u(t) \\
x^{2}(t+1)= & -0.5 x^{1}(t)+0.4 x^{2}(t)+0.2 u(t) \\
y(t)= & \sin \left(0.1 \pi x^{1}(t)\right) \\
x^{1}(0)= & x^{2}(0)=0
\end{aligned}
$$

とあらわされる 2 次系とし $(n=2)$, 規範モデルは,

$$
\begin{aligned}
& {\left[\begin{array}{l}
x_{M}{ }^{1}(t+1) \\
x_{M}{ }^{2}(t+1)
\end{array}\right]=\left[\begin{array}{cc}
1 & 0.2 \\
-0.6 & 0.4
\end{array}\right] x_{M}(t)+\left[\begin{array}{l}
0.3 \\
0.5
\end{array}\right] v(t)} \\
& y_{M}(t)=\left(\begin{array}{ll}
0 & 1) x_{M}(t) \\
x_{M}{ }^{1}(0)=0, & x_{M}{ }^{2}(0)=0.02
\end{array}\right.
\end{aligned}
$$

とする. また, 学習時の入力としては, 分散 1 平均 0 の 白色ガウス雑音を用い, 学習後の規範モデルへは,

$$
v(t)=\sin (0.04 \pi t)
$$

を入力した.

Fig. 5 (a) は6.の変換則 1, Fig. 5 (b) は変換則 2 を用いたときのシミュレーションである. 実線は制御対 象の出力 $y(t)$, 破線は規範モデルの出力 $y_{M}(t)$ である. 学習回数はともに, 30,000 回であり, 1,000 個の入出力 データを変換行列 $A$ を決定するために用いた. CMAC の定数は, $K=4, Q=11, N=2 n=4, g=0.7$ とし,

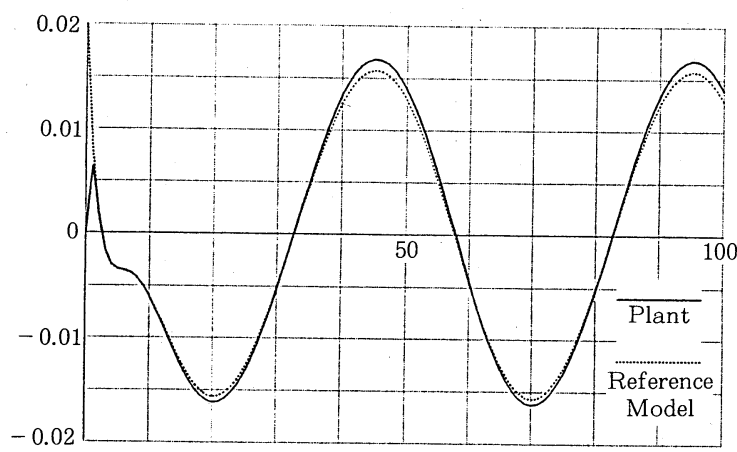

(a) Method of differences

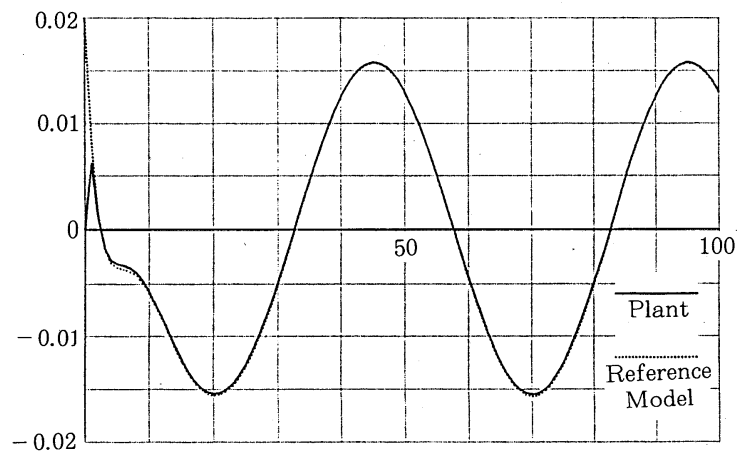

(b) Method of correlations

Fig. 5 Responses of outputs

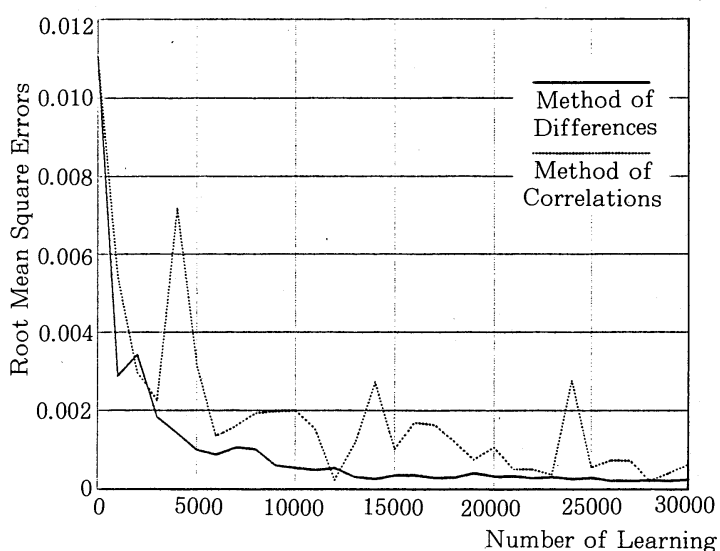

Fig. 6 Root mean square errors vs. number of learning

エラーシステムの極は $a=0.1$ である．また，Fig. 6 は， 学習回数によって追従の 2 乗平均誤差がどう変化するか を示している. 実線は変換則 2 の場合, 破線は変換則 1 の場合を示している.

Fig. 5 では，二つの方法ともに制御対象の出力が規 範モデルの出力に追従しているが, 変換則 2 の方がよく 追従していることがわかる，また，今回は図には載せな かったが，ARMA 同定によって得られた結果をもとに （26）式にしたがって線形制御則を構成した場合よりも, CMACを用いた方法がよりょく追従している. Fig. 6 に扔いても, 変換則 1 よりも変換則 2 の追従誤差が小さ いととがわかる. また，変換則 1 では学習回数が多くなっ ても追従誤差は上下しているが，変換則 2 では，ある一 定回数以上学習すると追従誤差はほとんど变化しない.

\section{8. 結 言}

ダイナミクスが未知である 1 入力 1 出力離散時間非線 形系に対する出力フィードバックのモデル追従制御則を, ニューラルネットワークの一種である CMAC に学習さ せる方法について述べた。

入力の過去值 $u(t-n+1), \cdots, u(t-1)$, 出力の過去 值 - 現在值 $y(t-n+1), \cdots, y(t)$, および次ステップに おける出力の目標值 $\phi\left(h_{M}\left(f_{M}\left(x_{M}(t), v(t)\right)\right), y(t)\right.$, $\left.y_{M}(t) ; a\right)$ にってモデル追従制御則が構成可能であ るととを2.，3で示し，5. ではこれらを CMACへの入 力として制御系を構成した。 さらに6. では，学習回数 · 追従誤差の低減を目的として, CMACへの入力に適当 な 1 次変換を挿入する方法を提案し, その変換法を二つ 示した. 7. ではシミュレーションを扟ない, 規範モ デルに制御対象の出力が追従することを確認した．また， このシミュレーションでは，6. で示した $\mathrm{CMAC}$ へ 入力の変換法のうち, 変換法 2 ( CMACへの入力を互 
いに無相関とする方法）の方が良好な性能を示している.

本論文の方法は，トラッキング・学習制御・モデル規 範型適応制御にも応用するととができると思われる.

おわりに，著者の一人にニューラルネットワークの制

御への応用に関する研究をおすすめいただいた室蘭工業 大学工学部情報工学科助教授長島知正先生, および参考 文献 18）をご紹介いただいた北海道大学工学部精密工学 科卒業生林伸善君（㑣 日本電気勤務, 現在宇宙開発事業 団に出向中）に厚く感謝します.

\section{参 考 文 献}

1) J.S. Albus : Brains, Behavior and Robotics ; McGrawHill (1981)（邦訳：ロボティクス ニューロンから知能ロ ボットへ, 啓学出版)

2). 狩野：神経回路モデル CMAC によるロボットマニピュレー 夕の学習制御；ロボットと生体の運動を探る（富士通侏国 際情報社会科学研究所第 5 回夏期シンポジウム報告書), pp. 164 173 (1988)

3) L. G. Kraft \& D. P. Campagna : A Comparison Between CMAC Neural Network Contol and Two Traditional Adaptive Control Systems ; IEEE Control Systems Magazine, Vol. 10, No. 3, pp. 36 43 (1990)

4) F.-C. Chen : Back-Propergation Neural Networks for Nonlinear Self-Tuning Adaptive Control ; IEEE Control Systems Magazine, Vol. 10, No. 3, pp. 44 48 (1990)

5) D. H. Nguyen \& B. Widrow : Neural Networks for Self-Learning Control Systems ; IEEE Control Systems Magazine, Vol. 10, No. 3, pp.18〜23 (1990)

6) 川人，宇野，鈴木：随意運動制御に打りる適応之制御 II ; 日本ロボット学会誌, 6 巻, 3 号, pp. 222〜230 (1988)

7) D. Psaltis, A. Sideris \& A. A. Yamamura : A Multilayered Neural Network Controller ; IEEE Control Systems Magazine, Vol. 8, No. 2, pp. 17 21 (1988)

8) 大松 : ニューラルネットワークと適応制御; コンピュート ロール, 32 巻, pp. 73 79 (1990)

9) D. E. Rumelhart, G. H. Hinton \& R. J. Williams : Learning Representations by Back-Propagating Errors ; Nature, Vol. 323, No. 9, pp. 533 536 (1986)

10) H.-G. Lee \& S. I. Marcus : On Input-Output Linearlization of Discrete-Time Nonlinear Systems ; Systems Control Lett., Vol. 8, No. 3, pp. 249 259 (1987)

11) S. Shin \& T. Kitamori : Model Reference Learning Control for Discrete-Time Nonlinear System ; Adaptive Systems in Control and Signal Processing 1989 (Proc. 3 rd IFAC Symposium on Adaptive Systems in Control and Signal Processing, Glasgow, UK, 1989), Pergamon Press, pp. 101 106 (1990)
12) S. Monaco \& D. Normand-Cyrot : Zero Dynamics of Sampled Nonlinear Systems ; Systems Control Lett., Vol. 11, No. 3, pp. 229 234 (1988)

13) S. T. Glad : Observability and Nonlinear Deadbeat Observers ; Proc. IEEE Conf. Dec. Control, pp. 800 $802(1983)$

14) E. D. Sontag : A Concept of Local Observability ; Systems Control Lett., Vol. 5, No. 1, pp. 41 47 (1984)

15) S. T. Glad : Output Dead-Beat Control for Nonlinear Systems with One Zero at Infinity ; Systems Control Lett, Vol. 9, No. 3, pp. 249 255 (1987)

16) J. W. Grizzle \& H. Nijmeijer ; On the Infinite Zeros of Nonlinear Discrete-Time Systems ; Theory and Applications of Nonlinear Control Systems, North-Holland, pp. 183 192 (1986)

17) S. Monaco \& D. Norman-Cyrot : Invariant Distributions under Sampling; Theory and Applications of Nonlinear Control Systems, North-Holland, pp. 215 221 (1986)

18）合原：ニューラルコンピュータ一脳と神経に学ぶー; 東京 電機大学出版局 (1988)

19) A. Isidori : Nonlinear Control Systems : An Introduction (2nd Edition); Springer-Verlag (1989) 